\title{
The optimization of distribution and transportation costs for common good products
}

\author{
Fibi Eko Putra ${ }^{a^{*}}$, Humiras Hardi Purbaa ${ }^{a}$ Indah Astri Anggraenib \\ aDepartment of Industrial Engineering, Universitas Mercu Buana, Jakarta, Indonesia \\ bDepartment of Management, Universitas Bhayangkara Jakarta Raya, Bekasi, Indonesia
}

${ }^{*}$ Corresponding Author: fibiekoputra@gmail.com

ARTICLE INFO

\section{Keywords}

Transportation Model;

Distribution;

North West Corner;

Stepping Stone.

\section{Article history}

Received:

June 24, 2020

Revised:

July 18, 2020

Accepted:

July 20, 2020

Available Online:

21 August, 2020

\author{
ABSTRACT
}

Transportation problems, which concerned in finding the minimum cost of transporting a single commodity from a given number of sources to a given number of destinations, are an integral part of the industrial system that has been around for a long time. The amount of potential losses caused by transportation problems have made many parties take initiatives and efforts to solve those problems, usually by designing an optimal distribution model. Current study employs two methods named North West Corner (NWC) and Stepping Stone (SS) method in order to find distribution model with the most optimal costs for common good products. Through this research, the NWC method is utilized to generate initial model or solution, while the SS method is used afterwards to find the optimal solution. According to it scheme, the result shows that through the NWC method there was cost reduction of $\$ 8,301$, while the distribution model obtained from the Stepping Stone method resulted in significant cost increased of $\$ 307,369$. Thus, it can be concluded that the use of single method, namely NWC method, in this study provides much better result than using the combined of NWC and Stepping Stone method.

\section{Introduction}

One important aspect in carrying out activities and influences the success of the industrial system is the transportation and distribution model that is applied in the industry. This is supported by the increasing consumer demand for products produced in various regions making transportation and distribution issues a major point in the company's development. Not infrequently we find consumers who complain about the high price of products set by producers in marketing their products. That is due to the addition of costs to the price of the product, namely operational costs resulting from transportation and distribution activities. The higher the cost of the product produced, the higher the price that must be set so that producers do not fall below the break even point. The high price is the reason why consumers are not loyal so they choose to look for other producers or find goods to substitute where there are many competitors for similar products. Transportation problem is famous in operation research for its wide application in real life (Mollah, et al., 2016). The transportation problem is concerned with finding the minimum cost of transporting a single commodity from a given number of sources to a given number of destinations (Kumaraguru, et al., 2014). Because there is only one commodity, a destination can receive requests from more than one source in order to determine how much must be sent from each source to each destination so as to minimize the total transportation costs (Aljanabi \& Jasim , 2015). 
The transportation method is expected to minimize transportation costs because transportation methods are designed to optimize the variables used to solve transportation problems (Chandra, 2016). Because the simplex method creates more difficult solutions, solving transport problems will be easier by using Stepping Stone, North-west Corner, Least Cost, and MODI method (Herlawati, 2016). The lack of North West Corner method is optimized again using the Stepping Stone method as a generator so that costs tend to be more optimal (Fatimah \& Wibawanto, 2015). At present the North West Corner approach to getting initial solutions is the most inefficient method; this method leads to a number of iterations that are very high relative to optimality (Mhlanga, et al., 2014). The North West Corner approach does not take into account costs when allocating to variables, resulting in an initial solution that provides an objective function value far from optimal (Sharma \& Bhadane, 2016).

\section{Literature Review}

The study carried out in the transportation method is the North West Corner method by assuming that the place of demand and supply is in the same area (Chandra, 2016). The transportation model uses the transfer principle, such as taking a hole from one place and entering it elsewhere without change (Evans-Obinna \& Nwosu, 2016). This is a method used to compute feasible solution of a transportation problem. In this method, the basic variables are usually chosen from the top left corner commonly referred to as the Northwest corner (Joshi, 2012). While the stepping stone method is used, evaluating empty cells (unallocated cells) and reallocate cells with highest negative (Aliyu, et al, 2019). To determine whether the allocation of each cell is optimal or not, it is necessary optimality testing by evaluating the cell are still empty (non basic variable) to find out if ever done sending a unit into an empty cell is whether to raise or lower the total costs. This testing process is called stepping stone method. (Ary, 2011). The north west corner and stepping stone method is used to determine a minimum cost of purchase and delivery of commodity occurred for some suppliers (Ary, 2013). A hybrid two-stage algorithm in solving transportation problems (Ramadan \& Ramadan, 2012). The zero-point method for transportation problems (Samuel, 2012). The sensitivity analysis and implementation of the well-known Vogel approach to the problem of unbalanced transportation (Juman, et al., 2013). A fast and simple branching algorithm in solving small-scale fixed-charge transportation problems (Kowalski, et al., 2014). Heuristic solution techniques to reach the minimum total cost limit for transportation problems with various demands and supplies (Juman \& Hoque, 2015). Efficient heuristics to obtain feasible solutions for a better start to the transportation problem. They pointed out the lack of new methods in developing methods to get basic solutions worthy of a better start (Juman \& Hoque, 2014). In a time transportation problem, the time of transporting goods from $\mathrm{m}$ origins to $\mathrm{n}$ destinations is minimized, satisfying certain condition in respect of availability at sources and requirements at the destinations. Thus the time minimizing transportation problem is:

$$
\text { Minimize } Z=\left[\operatorname{Max}_{(i, j)} t_{i j}: x_{i j}>0\right]
$$

Subject to

$\sum_{j=1}^{n} X_{i j}=a_{i} \quad i=1,2,3, \ldots, \ldots, \ldots, m$

$\sum_{i=1}^{m} X_{i j}=b_{i} \quad j=1,2,3, \ldots, \ldots, \ldots, n$

$X_{i j} \geq 0$

Here $t_{i j}$ is the time of transporting goods from the ith origin, where availability is $a_{i}$ to the $j^{t h}$ destination, where the requirement is $b_{j}$. For any given feasible solution, $X=\left[x_{i j}\right]$ satisfying (1), 
the time of transportation is the maximum of $t_{i j}{ }^{\prime} s$ among the cells in which there are positive allocations, i.e., corresponding to the solution $\mathrm{X}$, the time of transportation is:

$\left[\operatorname{Max}_{(i, j)} t_{i j}: x_{i j}>0\right]$

The aim is to minimize the time of transportation. Such problems arise when it is required to transport perishable goods during war days, it is required to transport food and armament in the shortest possible time and in so many other similar situations.

\section{Research Methodology}

At this stage the method for the initial solution used in this study is the North West Corner (NWC) Method. Meanwhile, the method for optimization used the Stepping Stone Method.

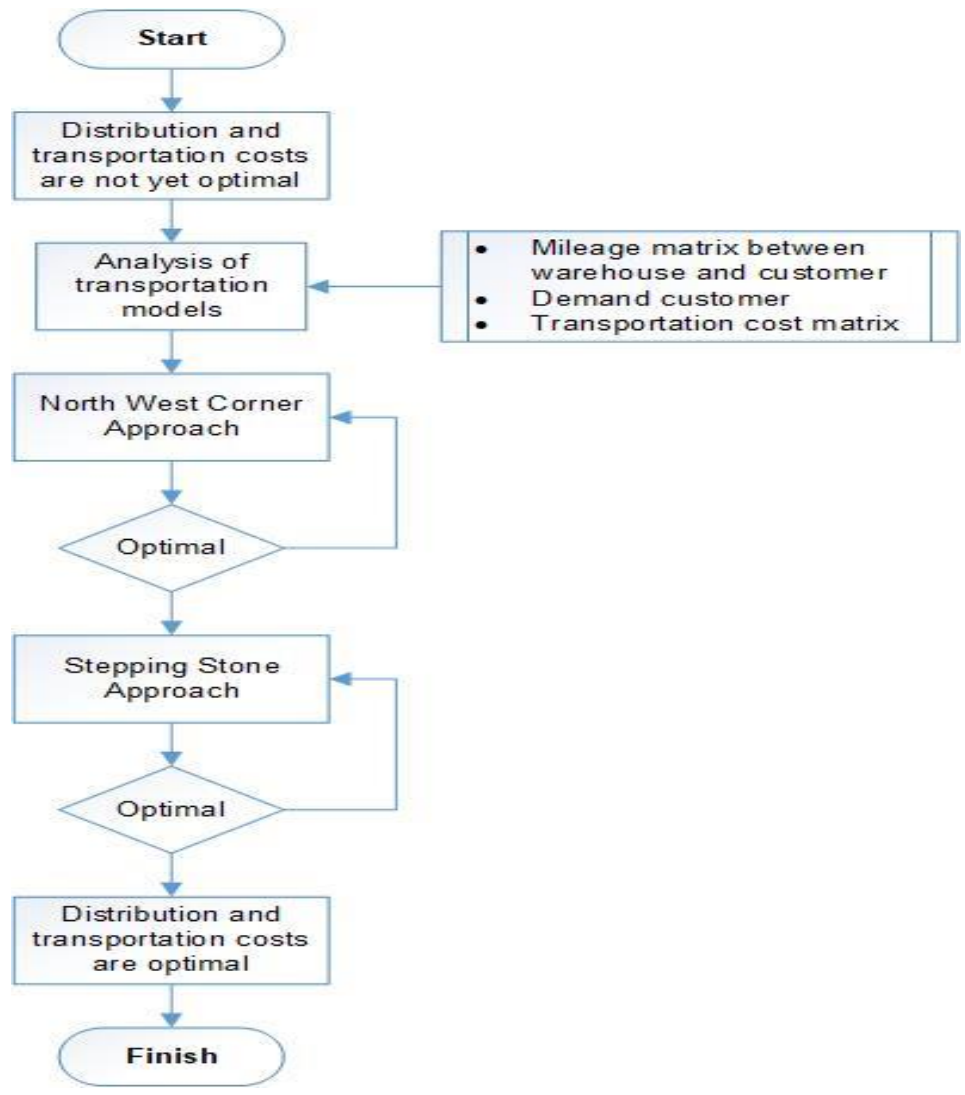

Figure 1. Research Flowchart

\section{Results and Discussion}

Given that the function as a warehouse is the starting point of departure of all fleets that will deliver logistics to the customer as well as the journey end point after completing all shipping points. In this study, logistics delivery cases in Jakarta, Bogor, Depok, Tangerang and Bekasi area provided by the warehouse have been taken. Data on the distance between the warehouse and the customer discussed in this paper will be presented in table 1. 
Table 1. Matrix Distance between Warehouse and Customers

\begin{tabular}{ccccccccc} 
DESTINATION & A & B & C & D & E & F & G & H \\
\hline A & - & 1,1 & 2,8 & 4,1 & 4,7 & 19 & 17 & 17 \\
B & 1,1 & - & 3,1 & 3,7 & 3,9 & 19 & 16 & 16 \\
C & 2,8 & 3,1 & - & 0,6 & 5,7 & 21 & 19 & 19 \\
D & 4,1 & 3,7 & 0,6 & - & 5,6 & 21 & 19 & 20 \\
E & 4,7 & 3,9 & 5,7 & 5,6 & - & 16 & 13 & 14 \\
F & 19 & 19 & 21 & 21 & 16 & - & 3,4 & 3,5 \\
G & 17 & 16 & 19 & 19 & 13 & 3,4 & - & 1,7 \\
H & 17 & 16 & 19 & 20 & 14 & 3,5 & 1,7 & -
\end{tabular}

Note:

The requirements needed to fulfill customer's demand discussed in the paper will be presented in Table 2.

Table 2. Sample Data of Customer Demand

\begin{tabular}{cc} 
CUSTOMER & CARBOARD \\
\hline MALL OF INDONESIA & 21 \\
ARTHA GADING MALL & 67 \\
KELAPA GADING MALL & 76 \\
LA PIAZZA & 11 \\
SUNTER MALL JAKARTA & 12 \\
BAYWALK PLUIT & 43 \\
EMPORIUM PLUIT & 35 \\
PLUIT VILLAGE & 40
\end{tabular}

Transportation costs are paid by the warehouse to the carrier or vendor that transports logistics from the warehouse to the customer based on interviews with relevant parties. In an interview, it was explained that the cost of transportation from the warehouse to the customer was $\$ 1,787$ per kilometer and the cost per carton was $\$ 0.965$. Following is the initial matrix cost table before research as follows. 


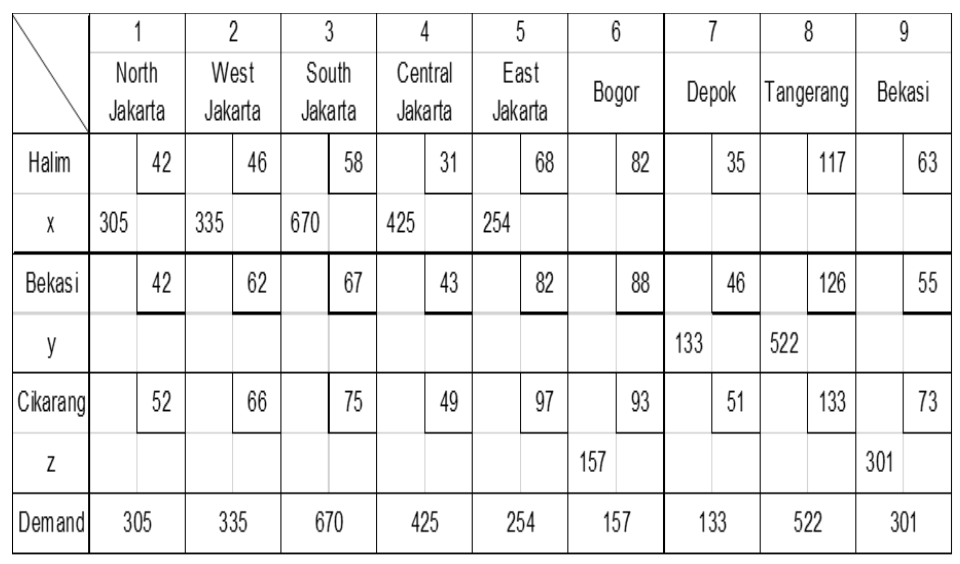

Figure 2. Current Distribution Method

$\begin{array}{lll}\text { Halim - North Jakarta } & =(305 \times 0,96)+(42 \times 1,78) & =\$ 369,37 \\ \text { Halim - West Jakarta } & =(335 \times 0,96)+(46 \times 1,78) & =\$ 405,47 \\ \text { Halim - South Jakarta } & =(670 \times 0,96)+(58 \times 1,78) & =\$ 750,19 \\ \text { Halim - Central Jakarta } & =(425 \times 0,96)+(31 \times 1,78) & =\$ 465,52 \\ \text { Halim - East Jakarta } & =(254 \times 0,96)+(68 \times 1,78) & =\$ 366,62 \\ \text { Bekasi - Depok } & =(133 \times 0,96)+(46 \times 1,787) & =\$ 210,54 \\ \text { Bekasi - Tangerang } & =(522 \times 0,96)+(126 \times 1,78) & =\$ 728,89 \\ \text { Cikarang - Bogor } & =(157 \times 0,96)+(93 \times 1,78) & =\$ 317,69 \\ \text { Cikarang - Bekasi } & =(301 \times 0,96)+(73 \times 1,78) & =\$ 420,91\end{array}$

Therefore, the total cost of transportation to distribute the products from the warehouse to the distributor using the North West Corner transportation model is $\$ 4.026,95$. The North West Corner application can minimize transportation costs from $\$ 4.035,251$ for distribution from warehouse to customer to $\$ 4.026,95$ it was can minimize of $\$ 8,301$ or $0.21 \%$ of the original cost. Having calculated using the North West Corner method, it is calculated to optimize the final solution using stepping-stone method with several levels until no negative results are obtained. Some steps in calculating the stepping stone method are as follows.

\begin{tabular}{|c|c|c|c|c|c|c|c|c|c|c|c|c|}
\hline & 1 & & ? & 3 & 4 & 5 & 6 & 7 & & 8 & 9 & \\
\hline & $\begin{array}{l}\text { Nothh } \\
\text { Jakatata }\end{array}$ & & atta & $\begin{array}{l}\text { South } \\
\text { Jakata }\end{array}$ & $\begin{array}{l}\text { Central } \\
\text { Jakata }\end{array}$ & $\begin{array}{l}\text { East } \\
\text { Jakata }\end{array}$ & Bogor & Depok & \multicolumn{2}{|c|}{ Tangerang } & Bekasi & \\
\hline Halim & 42 & & 46 & 58 & 31 & 68 & 82 & 3 & & 117 & 63 & \\
\hline x & & 335 & & 17 & 425 & 254 & & 133 & & & & \\
\hline Bekasi & 42 & & 62 & 67 & 43 & 82 & 88 & 4 & & 126 & 55 & \\
\hline y & 305 & & & 653 & & & & & 17 & & 301 & \\
\hline Cikarang] & 52 & & 66 & 75 & 49 & 97 & 93 & 5 & & 133 & 73 & \\
\hline$z$ & & & & & & & 157 & & 34 & & & $00 \mathrm{C}$ \\
\hline Demand & 305 & 3 & 5 & 670 & 425 & 254 & 157 & 133 & & 522 & 301 & 3102 \\
\hline
\end{tabular}

Figure 3. Optimal Solution Matrix with Stroke Step 6 
$x 1=42-43+67-58=8$

$x 6=82-58+67-126+133-93=5$

$x 8=117-58+67-126=0$

$x 9=63-58+67-55=17$

$\mathrm{y} 2=62-67+58-46=7$

$\mathrm{y} 4=43-31+58-67=3$

$\mathrm{y} 5=82-68+58-67=5$

$\mathrm{y} 6=88-93+133-126=2$

$\mathrm{y} 7=46-35+58-67=2$

$z 1=52-133+126-43=2$

$z 2=66-133+127-67+58-46=4$

$z 3=75-133+128-67=1$

$z 4=49-133+129-67+58-31=2$

$z 5=97-133+130-67+58-68=13$

$z 7=51-133+131-67+58-35=0$

$z 9=73-55+132-133=11$

Since there is no negative value, this solution is optimal. After the collection has been completed and the results obtained, the following is an optimization analysis of the distribution costs using the Stepping Stone method as follows.

\begin{tabular}{|c|c|c|c|c|c|c|c|c|c|c|c|c|c|c|c|c|c|c|c|}
\hline & & & & & & & . & & s. & & 6 & & 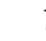 & & & & s. & & \\
\hline & $\begin{array}{l}\mathrm{No} \\
\text { Jak }\end{array}$ & & & & & & $\begin{array}{l}\text { Cer } \\
\text { Jak }\end{array}$ & & $\begin{array}{l}\text { E } \\
\text { Jak }\end{array}$ & & Bog & & $\mathrm{De}$ & & Tang & erang & Bel & & Otrer' \\
\hline Halim & & 42 & & 46 & & 58 & & 31 & & 68 & & 82 & & 35 & & 117 & & 63 & \\
\hline$x$ & & & 335 & & 17 & & 425 & & 254 & & & & 133 & & & & & & \\
\hline Bekasi & & 42 & & 62 & & 67 & & 43 & & 82 & & 88 & & 46 & & 126 & & 55 & \\
\hline$y$ & 305 & & & & 653 & & & & & & & & & & 177 & & 301 & & \\
\hline Cikarang & & 52 & & 66 & & 75 & & 49 & & 97 & & 93 & & 51 & & 133 & & 73 & \\
\hline z & & & & & & & & & & & 157 & & & & 345 & & & & \\
\hline Demand & 3 & & & & & & 4 & & 2 & & 157 & & 1 & & & & 3 & & 3102 \\
\hline
\end{tabular}

Figure 4. Optimization Phase
Halim - West Jakarta
$=(335 \times 0,96)+(46 \times 1,78)=\$ 405,47$
Halim - South Jakarta
$=(17 \times 0,96)+(58 \times 1,78)=\$ 120,05$
Halim - Central Jakarta
$=(425 \times 0,96)+(31 \times 1,78)=\$ 465,52$
Halim - East Jakarta
$=(254 \times 0,96)+(68 \times 1,78)=\$ 366,62$
Halim - Depok
$=(133 \times 0,96)+(35 \times 1,78)=\$ 190,89$
Bekasi - North Jakarta
$=(305 \times 0,96)+(42 \times 1,78)=\$ 371,16$
Bekasi - South Jakarta
$=(653 \times 0,96)+(67 \times 1,78)=\$ 749,87$
Bekasi - Tangerang
$=(133 \times 0,96)+(46 \times 1,78)=\$ 395,96$
Bekasi - Bekasi
$=(321 \times 0,96)+(126 \times 1,78)=\$ 388,75$
Cikarang - Bogor
$=(201 \times 0,96)+(133 \times 1,78)=\$ 317,69$
Cikarang - Tangerang
$=(301 \times 0,96)+(73 \times 1,78)=\$ 570,59$

Putra et al. 
The total cost of transport to distribute products from warehouses to customers by using North West Corner model of $\$ 4,035,251$. The North West Corner application can minimize transportation costs from $\$ 4,035,251$ for distribution from warehouse to distributor to $\$ 4,026,950$. The final solution to using a stepping stone is $\$ 4,342,620$. The increase in cost is $\$ 307,369$ or the increase in transportation costs is $7.62 \%$.

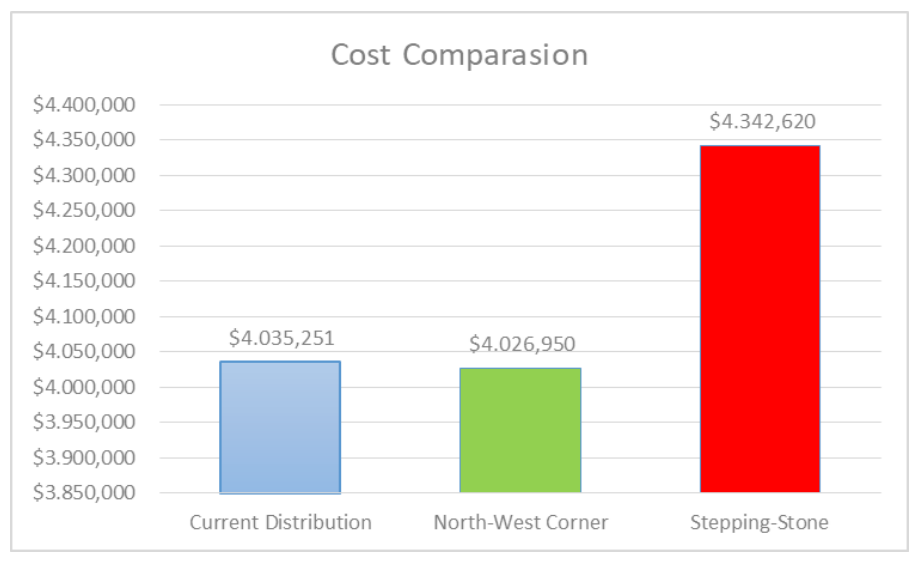

Figure 5. Cost Comparison Diagram

\section{Conclusion}

Based on the analysis and the results of the calculations that have been obtained, the conclusions can be taken on the implementation of the transport model. The conclusions obtained are from the results of the analysis, it is known that the adoption of the North West Corner transportation model can save the cost of distribution and Stepping Stone increase the cost of distribution. From the results of the calculations obtained shows that the reduction of transportation costs for optimum distribution is $\$ 8,301$. Based on the research used by the author in discussing the case, the analysis chapter shows the hypothesis is accepted because in the distribution process using the North West Corner, it can minimize the cost of transport from $\$$ $4,035,251$ for distribution from warehouse to distributor, to $\$ 4026,950$ Reduce the cost of $\$ 8,301$ or transportation costs kept by $0.21 \%$. Based on the analysis, the North West Corner approach is not relevant to be combined with the Stepping Stone cost distribution method because it increases distribution costs by $7.62 \%$ of the distribution costs using the North West Corner approach. Therefore there is a need for further research on the combination of the North West Corner approach with the Stepping Stone method in order to obtain optimal distribution cost results.

\section{References}

Aljanabi , K. B. S. \& Jasim , A. N., 2015. A New Algorithm For Solving Transportation Problem With Network Connected Sources. Journal of Kufa for Mathematics and Computer, pp. 8592.

Ary, M. 2011. Comparison the Transportation Problem Solution Betwen Northwest-Corner Method and Stepping Stone Method with Basis Tree Approach. Internasional Seminar on Scientific Issue and Trends (ISSIT), pp. A 35- 44. 
Ary, M. \& Herman, A. 2013. Basis Tree Approach And Nwc-Stepping Stone Method For Solving Transportation Problem With Fuzzy Cost. Internasional Seminar on Scientific Issue and Trends (ISSIT), pp. A 72- 82.

Chandra, T., 2016. Penerapan Algoritma North West Corner Dalam Penyelesaian Masalah Transportasi. Jurnal TIMES, pp. 12-16.

Evans-Obinna, R. N. \& Nwosu, E. E., 2016. Transportation Model: A Qualitative Solution Tool for Achieving Institutional and Managerial Goals in The 21st Century. International Journal of Quantitative and Qualitative Research Methods, pp. 1-9.

Fatimah, N. L. \& Wibawanto, H., 2015. Implementasi Pengoptimalan Biaya Transportasi dengan North West Corner Method (NWCM) dan Sepping Stone Method (SSM) untuk Distribusi Raskin pada Perum Bulog Sub Divre Semarang. Edu Komputika Journal, pp. 48-54.

Herlawati, 2016. Optimasi Pendistribusian Barang Menggunakan Metode Stepping Stone dan Metode Modified Distribution (MODI). Information System For Educatiors And Professionals, pp. 103-113.

Juman, Z. A. M. S. \& Hoque, M. A., 2014. A Heuristic Solution Technique to Attain The Minimal Total Cost Bounds of Transporting a Homogeneous Product with Varying Demands and Supplies. European Journal of Operational Research, pp. 239: 146-156.

Juman, Z. A. M. S. \& Hoque, M. A., 2015. An Efficient Heuristic to Obtain a Better Initial Feasible Solution to The Transportation Problem. Applied Soft Computing, pp. 34: 813-826.

Juman, Z. A. M. S., Hoque, M. A. \& Buhari, M. I. A., 2013. Sensitivity Analysis and an Implementation of The Well-Known Vogel's Approximation Method for Solving Unbalanced Transportation Problems. Malaysian Journal of Science, pp. 32(1): 66-72.

Joshi, R. V., 2013. Optimization techniques for transportation problems of three variables. IOSR Journal of Matematics (IOSR-JM), Vol. 9, pp. 2278-5728.

Kowalski, K., Lev, B., Shen, W. \& Tu, Y., 2014. A Fast and Simple Branching Algorithm for Solving Small Scale Fixed-Charge Transportation Problem. Amsterdam, Elsevier, pp. Vol. 1, Iss. 1, pp. $1-5$, .

Kumaraguru, S., Kumar, S. B. \& Revathy, M., 2014. Comparitive Study of Various Methods for Solving Transportation Problem. International Journal of Scientific Research, p. 2277 8179.

M.L. Aliyu, U. Usman, Z. Babayaro and M.K. Aminu. 2019. A minimization of the cost of transportation, American Journal of Operational Research, Vol. 9, No. 1, pp. 1-7.

Mhlanga, A., Nduna, I. S., Matarise, F. \& Machisvo, A., 2014. Innovative Application of Dantzig's North - West Corner Rule to Solve a Transportation Problem. International Journal of Education and Research, pp. Vol. 2 No. 2:1-12.

Mollah, M. . A., Aminur, R. K., Md., S. U. \& Faruque, A., 2016. A New Approach to Solve Transportation Problems. Open Journal of Optimization, pp. 22-30. 
Ramadan, S. Z. \& Ramadan, I. Z., 2012. Hybrid Twostage Algorithm for Solving Transportation Problem. International Journal of Physics and Mathematical Sciences , pp. 6(4): 12-22.

Samuel, A. E., 2012. Improved zero point method (IZPM) for the transportation problems. Applied Mathematical Sciences, Volume 6, pp. 5421-5426.

Sharma, N. M. \& Bhadane, A. P., 2016. An Alternative Method to North-West Corner Method for Solving Transportation Poblem. International Journal for Research in Engineering Application \& Management, pp. Vol. 1 Issue 12:1-3. 
This page is intentionally left blank. 